Article

\title{
Collaboration for Sustainability in the Food Supply Chain: A Multi-Stage Study in Italy
}

\author{
Verónica León-Bravo ${ }^{1,2, *}$, Federico Caniato ${ }^{1}$ [D, Maria Caridi ${ }^{1}$ and Thomas Johnsen ${ }^{1}$ \\ 1 Department of Management, Economics and Industrial Engineering, Politecnico di Milano, \\ Via Lambruschini 4, 20156 Milan, Italy; federico.caniato@polimi.it (F.C.); maria.caridi@polimi.it (M.C.); \\ thomaserik.johnsen@polimi.it (T.J.) \\ 2 Facultad de Posgrados, Universidad de las Américas, Av. José Queri entre Av. Granados y Av. Eloy Alfaro, \\ 170122 Quito, Ecuador \\ * Correspondence: claritaveronica.leon@polimi.it or veronica.leon@udla.edu.ec; \\ Tel.: +39-388-9732-188 or +593-982-093-661
}

Received: 25 May 2017; Accepted: 14 July 2017; Published: 18 July 2017

\begin{abstract}
The objective of this study is twofold. Firstly, to analyze sustainability practices adopted in collaboration, including vertical collaboration i.e., with other actors or stages upstream or downstream in the supply chain, and horizontal collaboration i.e., with actors such as non-governmental organizations (NGOs). Secondly, to identify the sustainability performance expected from sustainability practices implemented in different supply chain stages. The study reports on a set of case studies representing four different food supply chain (FSC) stages: breeding/growing, processing, distribution and retail. The findings indicate that each stage selects different collaboration schemes for sustainability practices' implementation, prioritizing relations with upstream actors, namely grower/breeder, as these are key actors responsible for ensuring product quality and safety. In addition, the type of collaborative relationship is shown to be predominantly transactional for environmental and community practices, especially for solving specific short-term issues. Finally, varied areas of environmental and social sustainability performance are recognized, upstream and downstream, as a result of collaborative practices applied in different FSC stages, showing the diverse sustainability objectives pursued along the chain.
\end{abstract}

Keywords: sustainability collaboration; sustainable supply chain; food supply chain

\section{Introduction}

Food is one of the industries where sustainability issues are intrinsically embedded because of the amount and variety of natural resources usage, human requirements for basic nutrition, and communities depending on food production for survival. However, improving sustainability in the food industry requires engagement of actors worldwide, in order to cope with the challenges of consumer expectations, limited resources, international policies and regulations [1].

Authors highlight the importance of supply chain collaboration in order to succeed in the sustainability journey. Focusing on environmental sustainability, Vachon and Klassen [2] defined collaborations as the interactions between supply chain (SC) members for shared environmental goals, which can be directed upstream or downstream, and are expected to be intra and/or inter-organizational [3]. Thus, identifying who participates in collaboration initiatives and the goals involved is key to establishing a successful relationship. However, different tiers, or "stages", in the supply chain might have different sustainability strategies and goals, and decisions such as the type of collaboration, with whom and for what reasons, become crucial to understand [4].

In the food industry, the implementation of sustainability practices has spread and studies have analyzed their impact on performance i.e., quality, efficiency, flexibility and responsiveness [5]. 
Nonetheless, there is scarce identification of sustainability practices applied in collaboration, across different supply chain stages. Authors have suggested that collaboration can make a difference in the application of certain practices as well as their respective performance outcomes [2,3,6,7]. However, to the best of our knowledge, few studies have analyzed sustainability performance outcomes expected from collaborative sustainability practices in different supply chain stages. Therefore, this study intends to fill this gap in current research, analyzing the type of collaboration for sustainability implemented in different food supply chain (FSC) stages in order to obtain a wider supply chain view, and explore the performances aimed at when setting up collaborative sustainability practices.

Sustainability performance represents the attainment of a sustainability-attained goal. Research studies on SC sustainability performance and specifically in the FSC have largely focused on metrics definition, usually on one supply chain stage i.e., the focal company [8,9]. Measures proposed are mainly environmentally oriented in order to respond to external pressures and regulations [10]. Likewise, companies and researchers have recently included social indicators [9,11-14]. This study analyzes both the environmental and social performance resulting from collaboration within different supply chain stages.

We rely on Resource Dependence Theory (RDT) to analyze the collaborative relations in the FSC. RDT explains how firms are dependent on resources provided by others in order to sustain growth, as well as other organizations that may be dependent on them [15]. As organizations are not autonomous, they create relationships that grant them access to the resources they need [16]. Collaboration is one of the strategies identified in RDT for firms to minimize environmental dependences [15]. In the same line, collaboration for sustainability could help to reduce dependence among supply chain actors in order to accomplish sustainability goals. Nonetheless, it is relevant to mention that collaboration could bring several problems as well due to the investments and organizational changes needed, the potential increase of dependence, and complexity to manage extra relationships $[4,6]$.

The objectives of this paper are twofold. First, to identify the sustainability practices that companies working in different FSC stages have implemented in collaboration, and the type of relationship set up. Second, to identify the sustainability performance expected as a result of those collaborations. Based on a set of exploratory cases across four FSC stages, we have conducted within case, cross-case and cross-stage analysis. The results show how collaboration for sustainability in the FSC is deployed with a variety of actors, within the chain or with external organizations. Additionally, the sustainability performance resulting from those collaborations depends on several factors as company size, product type, or SC position.

The paper is organized as follows: first, we present the conceptual background of sustainability practices and performance in the FSC and the role of supply chain collaboration. We then present the research design and methodology and findings and analysis of the cases. Finally, we discuss the implications for research and practitioners and openings for further research.

\section{Conceptual Background}

\subsection{Food Supply Chain Management and Sustainability}

The sustainability triangle [17] or the three sustainability pillars [18], namely economic, social and environmental, are in constant interaction in the food industry. Some of the sustainability concerns in the FSC involve the usage of natural resources, emissions, animal welfare, consumer health, food quality and safety, ethical conditions at work, and affordability for consumers $[1,17,19]$. For instance, regarding food production, the FAO [20] states that "global food production must increase by $60 \%$ by 2050 in order to meet the demands of the growing world population" in order to reduce world hunger, while there is a need to observe resource capacity and to reduce food waste at the same time.

Therefore, the sustainability challenges in the food industry are numerous. Actors in the FSC need to consider several objectives simultaneously in three areas that could be thought as contradictory [21]. Research in FSC sustainability has studied a diversity of aspects mentioned before such as consumer 
expectations, supplier's development and fair trade, community development, logistics operations, waste management and the performance outcomes related [5,10,12,21-23]. In addition, as Fritz and Schiefer (2008) [15] suggested, to "build on an economically viable and socially acceptable development" there is a need of participation of several actors in a collaborative manner for achieving the best for everyone.

\subsection{Collaboration for Sustainability in the Food Supply Chain (FSC)}

Literature on supply chain management has drawn attention to the need for collaboration between supply chain actors as a component of success [6]. The growing demand for improved service levels and rising costs for offering better quality products recognize collaboration in the supply chain as a key driver to increase business performance and sustainability $[3,6,18,24]$.

In this section, first, collaboration in the supply chain, its characteristics and typologies are defined. Then, collaboration for supply chain sustainability is described. At the basic level, supply chain collaboration refers to companies and/or organizations working together to solve problems and/or achieving common goals [3,4,7]. However, supply chain collaboration is difficult to manage because of challenges regarding the decisions surrounding with whom and when to collaborate, for what reasons and how to implement collaboration [4]. Therefore, it is necessary to understand the context and the type of collaborative relationship between partners to achieve the most suitable results.

Collaboration in the supply chain can be of different types. Barrat (2004) [4] identified two main typologies: vertical (i.e., with customers, with suppliers) and horizontal (i.e., with competitors and other organizations). For a collaboration initiative to be successful, cultural and strategic elements need to be considered e.g., trust, corporate focus, intra-organizational support, communication [25]. In this context, Barrat also highlights the importance of focusing "on the small number of close relationships rather than trying to collaborate with everyone" [4], because collaboration implies high resources investment. Likewise, Whipple and Russell (2007) in [26] classified three types of collaborative approaches named: transaction, event and, process. The first refers to operational level decisions and transactional data exchange. The second implies more tactical decisions with joint planning for solving specific issues. The third refers to a more strategic level of involvement and to fully integrated processes [26]. The authors differentiate the focus, objectives and payoffs in each typology, underlining that each one implies a distinct management strategy, different level of people interaction and return expected from the relationship $[7,25,26]$.

Collaboration for sustainability in the supply chain is a relatively new topic in literature [26,27] Literature has studied "green" collaborative relationships in the supply chain but a broader sustainability perspective, including economic, environmental and/or social areas, is rather unusual $[25,28,29]$. Nonetheless, authors recognized that collaboration for sustainability would help firms to develop resources and competences that otherwise would not be possible, with the ultimate goal of achieving competitive advantage [2,7,18,27-29].

In spite of all the benefits that collaboration in the supply chain could provide, it faces several barriers in the food industry. The intrinsic structure of the FSC where companies are different in terms of product characteristics, size, location and access to ICT adversely affects the collaboration they could establish, also because of their different bargaining power. Companies in this industry must consider the challenges in identifying what activities are feasible to collaborate in, with whom and what are the related expected benefits and barriers [6,25].

Nonetheless, considering specifically collaboration for sustainability, other authors argued that the complexity and heterogeneity in the food industry actually motivate companies to collaborate at different levels [24]. Ramanathan et al. (2014) in [3] suggested three levels of green collaboration in order to improve sustainability in production, supply and distribution. Additionally, researchers have identified a key factor for successful green collaboration is information sharing, including data relative to strategies and requirements among all supply chain partners [3,27]. However, there is 
limited evidence, to our knowledge, of collaborative typology identification collecting evidence from more than a single or focal company in the supply chain.

Furthermore, companies are encouraged to get involved in collaborative initiatives as supply chain collaboration has a bottom-line influence on firm performance $[2,7,27,30]$. However, as recognized by $[28,29]$, studies have focused on analyzing environmental and operational collaboration and the social perspective is still rarely studied.

\subsection{Sustainability Performance in the FSC}

Sustainability is often presented as a goal in businesses, nonprofits and governments; however, measuring the degree to which an organization is being sustainable can be difficult to achieve because beyond economic performance measurement, environmental and social are difficult to quantify [31,32], and multiple actors are involved in the chain. Often, only one or two out of the three sustainability pillars is evaluated, being the environmental or, economic and environmental, aspects considered the most [31]. However, numerous practitioner initiatives and research contributions have been developed over the years for that evaluation. For instance, regarding the environmental performance, several metrics and measurement systems have been proposed e.g., energy and resource consumption, carbon emissions, and waste generation. Similarly, regarding social performance, the evaluation areas proposed in literature include ethical behavior, stakeholder engagement, human rights observance and occupational safety. These types of metrics, indicators or measurement areas have been described in general and specifically for the food industry [9,11,12,14,33-35]. For instance, some studies focused on the environmental impact for industries in general $[2,23,36]$, or particularly for food $[21,33]$. Others have analyzed the social pillar in food industry, identifying global issues as fair trade, nutrition, community involvement, consumer respect, employee motivation and rewards [11,12,22,23]. Regarding economic sustainability, research has been oriented to in-company processes or quality improvement in order to reduce cost and/or to increase sales [5,17]. Above all, most research contributions have engaged individual company scenarios, implying the focal company being responsible for the measurement [31], or have taken into account a supplier-customer relationship [5,21].

More recent studies [37] have studied multi-tier supply chains to understand the complexities in such scenarios. Yet, several authors have pointed out that beyond the sustainability metrics and reporting, it would be important to understand how collaboration for sustainability in the supply chain is related to sustainability performance, including the social dimension, in the supply chain.

\subsection{Theoretical Background}

Resource Dependence Theory (RDT) is a suitable lens to study sustainable supply chain management (SSCM) [38,39]. Common issues of RDT and SSCM are, for instance, the actor's dependency on each other about key resources that determine companies' sustainability. Additionally, RDT studies the relationships established to deal with such dependencies [38] that reduce or increase power of resource's providers $[15,16]$. RDT suggests that firms in a supply chain should collaborate to gain long-term performance given that firms are interdependent on resources, meaning that organizations are not autonomous but rather constrained by a network of interdependencies [38]. Moreover, RDT suggests that supply chain actors depend on and collaborate to seek higher performance gains in the long run instead of pursuing short-term benefits at the expense of others [15,38]. In terms of sustainability, RDT could explain how partner coordination and resource sharing are beneficial for environmental and productivity improvements [38].

Companies operating in different parts of the FSC depend on each other to ensure product availability and certain product characteristics e.g., quality and safety, efficient delivery times. RDT proposes five strategies for firms to minimize environmental dependencies: mergers/vertical integration, joint ventures /inter-organizational relationships, boards of directors, political action, and, executive succession [15]. In this study, the first and second strategy i.e., vertical integration and inter-organizational relationships will be observed for analyzing the behaviors of companies in the 
FSC. With these strategies, firms expect to manage interdependencies with input sources and output purchasers, or, to gain power over resource providers with alliances [15].

\section{Research Design}

\subsection{Research Objectives and Questions}

Several authors suggest that supply chain collaboration can influence a company's performance $[3,6,18,24,25,27]$. However, investigation in the FSC in respect of collaboration for sustainability and specifically, analyzing the performance effects of such relationships has been sparsely researched. The study of [28] shows that previous research has focused on collaboration for sustainability prioritizing the environmental and economic dimensions, and highlights that social issues should be considered as well. Regarding performance effects from collaboration, usually the focal company is considered the responsible for the performance measurement [31].

Collaboration implies that a degree of alignment should exist for starting such a relationship, though, different stages in the supply chain might have different sustainability strategies and goals, and the decisions regarding the type of collaboration, with whom and for what reasons, is crucial. Focusing on the FSC, this study intends first to identify the sustainability practices that companies working in a certain FSC stage implemented in collaboration with other supply chain stages or with external actors. Second, to find out the sustainability performance i.e., environmental and social, expected as result of the practice application. We seek to answer the following research questions:

1. What are the sustainability practices implemented in collaboration, in different FSC stages?

1.1. What are the types of collaborations implemented by different FSC stages?

2. What is the sustainability performance expected from the sustainability practices implemented in collaboration?

The research framework depicted in Figure 1 shows that the first research question is to be answered per FSC stage, that is, to identify the collaboration practices applied in each FSC stage. The sustainability practices are investigated in the environmental, economic and social dimensions. Then, for the second question, the attention is in observing the sustainability performance, specifically environmental and social, envisaged in the stages upstream and downstream, as benefit from the collaborative practices adopted. In the following sections, we detail the variables under study as suggested by [40].

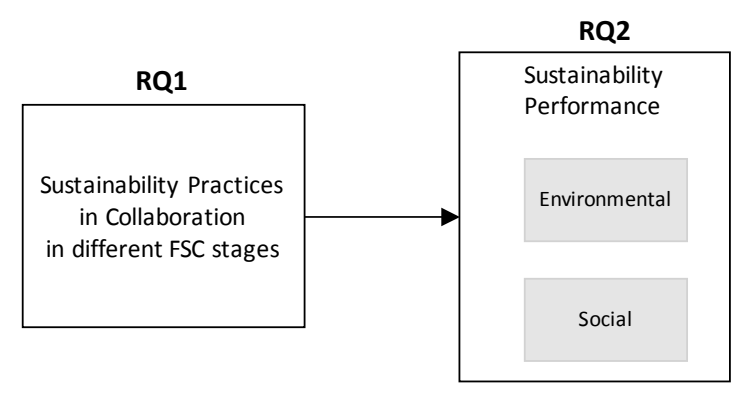

Figure 1. Research framework.

\subsection{Research Question 1: Sustainability Practices in Collaboration}

Table 1 presents the sustainability practices categorization that we adopted in this study. The practices listed here are classified in seven dimensions based on the triple bottom line. We propose this categorization taking into account different frameworks and contributions in literature and industry $[10,19,20,41-46]$. Hence, Table 1 contemplates specifically sustainability practices in the food industry taking into account factors considered relevant in the FSC applicable in different stages, from growers to retailers. 
Table 1. Sustainability practices in food industry.

\begin{tabular}{|c|c|c|}
\hline Sustain & bility Dimension & Example of Practices \\
\hline \multirow[b]{2}{*}{ Environment } & $\begin{array}{l}\text { Natural Resources } \\
\text { conservation (NRC) }\end{array}$ & $\begin{array}{l}\text { Animal Welfare: Elimination of cruelty; safe handling, housing, slaughter } \\
\text { and transport } \\
\text { Soil conservation: Conservation forest, species; prevent soil erosion and } \\
\text { pollution, prevent loss of arable land and biodiversity, responsible farming } \\
\text { methods (reducing fertilizer and pesticides), elimination of contaminant and } \\
\text { pollutant agents } \\
\text { Water conservation: reducing water consumption, efficient water use, waste } \\
\text { water re-use and recovery }\end{array}$ \\
\hline & $\begin{array}{l}\text { Green processing, } \\
\text { packaging and } \\
\text { transportation (GPPT) }\end{array}$ & $\begin{array}{l}\text { Design, materials and packaging: effective design for reuse and recycling, use } \\
\text { of design for disassembly and reuse, material reuse and recycle, reducing } \\
\text { packaging, using reusable/recyclable packaging } \\
\text { Waste: reduce waste and hazardous materials, composting organic waste, } \\
\text { producing renewable energy or animal feed with waste, lower disposal costs, } \\
\text { damage compensation, recycling } \\
\text { Processing and transportation: reducing energy use, conservation of energy, } \\
\text { reducing } \mathrm{CO}_{2} \text { emissions and GHGs, reduce pollution, reduction of } \\
\text { fuel consumption }\end{array}$ \\
\hline \multirow{3}{*}{ Social } & Health and Safety (H\&S) & $\begin{array}{l}\text { Improved product quality, food safety, food security, traceability and } \\
\text { transparency. Promotion of healthy life styles and local food sources. Safer } \\
\text { warehousing and transportation }\end{array}$ \\
\hline & $\begin{array}{l}\text { Work and Human Rights } \\
\text { (W\&HR) }\end{array}$ & $\begin{array}{l}\text { Better working conditions that result in higher levels of motivation and } \\
\text { productivity and less absenteeism. Training, education, advancement. } \\
\text { Regular employment, elimination of illegal and child labor, respect of worker } \\
\text { rights, gender equality, freedom of association, safe working conditions }\end{array}$ \\
\hline & Community & $\begin{array}{l}\text { Donation, collaboration with NGOs, philanthropy, support to the economic } \\
\text { development in local communities, educational practices, health care, } \\
\text { job training, volunteering, childcare }\end{array}$ \\
\hline \multirow[t]{2}{*}{ Economic } & Sustainable sourcing (SS) & $\begin{array}{l}\text { Increasing supplier diversity, confidentiality, eliminating deception and } \\
\text { impropriety, transparency, proper purchasing processes (reciprocity, fairness, } \\
\text { no power abuse or special treatment), supplier's labor programs, local } \\
\text { sourcing that result in shorter lead-times. Environmental and social } \\
\text { considerations when selecting, monitoring and controlling suppliers. }\end{array}$ \\
\hline & Support SC partners & $\begin{array}{l}\text { Profit sharing with actors in the upstream supply chain, premium price } \\
\text { payment, support and monitoring for obtaining sustainability certification. } \\
\text { Facilitate partners' access to markets, knowledge and technology transfer, } \\
\text { fostering financing opportunities, information and expertise sharing. }\end{array}$ \\
\hline
\end{tabular}

Research question 1.1 seeks to identify the types of collaborative relationships that different FSC stages set up, and to classify these according to the propositions in [2] and in [26].

Firstly, Vachon and Klassen in [2] stated that collaboration for sustainability can be vertical or internal to the supply chain i.e., upstream and downstream in the chain; and horizontal and external to the chain. Regarding vertical collaboration upstream or downstream in the chain, Vachon and Klassen refer to environmental collaboration as the interaction between organizations in the supply chain for sharing environmental expertise or knowledge and, working together to attain environmental goals. Furthermore, this logic is extended to social collaboration e.g., working for community development, fair trade, or employee well-being. Thus, collaborations can be of any type, from information exchange, up to projects involving assets sharing and operational involvement of both actors, to achieve a sustainability goal, for one or other actor in the supply chain. For horizontal or external collaborations, we consider interactions with governments, NGOs, financial institutions and certification organizations. This type of collaboration has been rarely studied in literature, as pointed out by [28] and is of interest in our study because companies in the FSC actually interact with other organizations outside the chain as regulators, NGOs, financing operators, among others [10,19].

Moreover, the collaborative relationship can be related to a transaction, an event or a process [26], whose characteristics are summarized in Table 2. 
Table 2. Types of collaborative relationships in the supply chain (adapted from [26]).

\begin{tabular}{|c|c|c|c|}
\hline Characteristic & Transaction & Event & Process \\
\hline Organizational level & Operational & Tactical & Strategic \\
\hline Time horizon & Short term & Medium term & Long term \\
\hline $\begin{array}{l}\text { Level of people } \\
\text { interaction }\end{array}$ & $\begin{array}{l}\text { Limited } \\
\text { person-to-person } \\
\text { interaction }\end{array}$ & $\begin{array}{l}\text { Person-to-person interaction } \\
\text { focused on joint decision for the } \\
\text { collaboration focus }\end{array}$ & $\begin{array}{l}\text { Person-to-person interaction } \\
\text { focused on developing } \\
\text { cross-functional processes }\end{array}$ \\
\hline Process characteristics & $\begin{array}{l}\text { Data exchange and } \\
\text { task alignment }\end{array}$ & $\begin{array}{l}\text { Joint planning and decision making } \\
\text { for specific events or issues }\end{array}$ & Fully integrated process \\
\hline Knowledge level & Explicit & Explicit and some level of tacit & Explicit and high levels of tacit \\
\hline $\begin{array}{l}\text { Return expected from } \\
\text { the relationship }\end{array}$ & $\begin{array}{l}\text { Reduced problems } \\
\text { and-or errors on tasks }\end{array}$ & $\begin{array}{l}\text { Performance improvements are } \\
\text { more impact oriented }\end{array}$ & $\begin{array}{l}\text { Performance improvements to } \\
\text { focus on future events }\end{array}$ \\
\hline
\end{tabular}

The identification of type of collaborative relationship implemented is the first step in our analysis that will help to better describe the sustainability approach in different FSC stages. Furthermore, collaboration for sustainability in the supply chain is said to have an effect on performance as mentioned in previous literature $[2,7,28,29]$. However, research has focused so far on the focal company performance that is described as the actor actually driving the collaboration. Hence the intention in this study is to extend the analysis to the understanding of the performance effect on other supply chain stages.

\subsection{Research Question 2: Sustainability Performance in the FSC}

Several contributions in the supply chain literature propose sustainability indicators, metrics or evaluation systems in the environmental and social aspects [9-14,47]. Previous literature has identified that mostly environmental and economic performance are considered in sustainable supply chain studies $[2,7,28,31]$, therefore for the aims of this study, we concentrate on the environmental and social dimensions. The performance areas that we considered are summarized in Table 3.

Table 3. Sustainability performance areas in the FSC (summarized from [9-14,47]).

\begin{tabular}{cc}
\hline Environmental & Social \\
\hline Water consumption & \\
Energy consumption & Labor practices and decent work \\
Waste generation & Human rights observance \\
$\mathrm{CO}_{2}$ emissions & Training per employee \\
Number of certified suppliers & Work safety procedures \\
Use of renewable energy & Diversity \\
Use of recycled material & Fair pay systems \\
Fuel use & Investments in social projects \\
Effectiveness of reverse logistics system & Code of conduct \\
Effectiveness of supplier monitoring & Food health and safety \\
Animal welfare & Community wellbeing \\
Soil protection & \\
\hline
\end{tabular}

\section{Research Methodology}

We applied a multiple case study methodology focusing on different FSC stages, as depicted in Figure 2, with the aim of exploring collaboration for sustainability collaboration and the sustainability performance expected. This way, the intention is to gain insights through pattern and relationships recognition among the variables that we investigated, by means of a within-case and cross-case analysis $[40,48,49]$.

The innovativeness in this study is to consider multiple stages along the supply chain, with multiple cases per stage. This approach, though of higher complexity, implies a wider FSC view and the identification of different behavior along the chain. The unit of analysis is the company with activities in a certain FSC stage. The four selected stages are growing/breeding, processing, distribution and retail; this way covering the main adding-value steps in the food supply chain. 


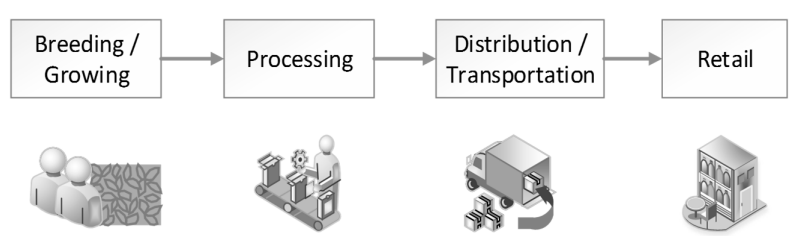

Figure 2. Food Supply Chain stages considered in the study.

\subsection{Case Selection}

The collection of cases follows the suggestions in [40,49] of considering opposite cases that may represent contrasting realities of the phenomenon under study, following replication logic. Therefore, the companies selected for this study have different size, work with different types of products and represent different supply chain stages. This selection is expected to lead to clear pattern and relationship recognition [49].

Table 4 summarizes the set of cases in this study, composed of 15 companies. Five of them have some levels of vertical integration and work in more than one stage of the FSC, thus representing more than one unit of analysis. For instance, cases I, J, K belong to the same company and will be analyzed according to the supply chain stages where they operate. In those five cases the collaboration practices for sustainability as well as the performance related will be inquired individualizing each FSC stage they work in. Aside of each company's strategy, our intention is to identify the type of collaborative practices that each FSC stage implements and being able to compare with other companies in the same stage.

Figure 3 graphically illustrates the sample distribution in the different FSC stages, as well as the representative company size.

Table 4. General description of the cases under study.

\begin{tabular}{|c|c|c|c|c|}
\hline Case & Industry Sub-Sector & FSC Stage & $\begin{array}{l}\text { Sales } 2013 \\
\text { (million } € \text { ) }\end{array}$ & Employees \\
\hline A & Food products retail & Retail & 63.09 & 757 \\
\hline B & $\begin{array}{l}\text { Production of chocolate and semi-finished products for the } \\
\text { confectionery industry }\end{array}$ & Processing & 109.27 * & 262 \\
\hline $\mathrm{C}$ & Canned food production based on: fish, meat, seasonings and tuna & Processing & 719.11 & 757 \\
\hline $\mathrm{D}$ & Hypermarket retail & Retail & 2656.48 & 9777 \\
\hline $\mathrm{E}$ & Beer production & Processing & 774.37 & 974 \\
\hline $\mathrm{F}$ & Semi-finished products made with nuts for confectionery and ice cream industry & Processing & $4.64 *$ & 18 \\
\hline G & Vegetables cultivation & Growing & \multirow{2}{*}{6.95} & \multirow{2}{*}{30} \\
\hline $\mathrm{H}$ & Fruit and vegetables: processing and sales & Processing & & \\
\hline I & Vegetables cultivation & Growing & \multirow{3}{*}{$110.52 *$} & \multirow{3}{*}{290} \\
\hline $\mathrm{J}$ & Fruit and vegetables: processing and sales & Processing & & \\
\hline K & Distribution of finished products based on vegetables and fruits & Distribution & & \\
\hline $\mathrm{L}$ & Preserved pastry production & Processing & $345.72 *$ & 1065 \\
\hline M & Vegetables cultivation & Growing & \multirow{2}{*}{64.26} & \multirow{2}{*}{380} \\
\hline $\mathrm{N}$ & Fruit and vegetables: processing and sales & Processing & & \\
\hline $\mathrm{O}$ & Livestock breeder & Breeding & \multirow{2}{*}{43.81} & \multirow{2}{*}{125} \\
\hline $\mathrm{P}$ & Dairy production and sales & Processing & & \\
\hline Q & Beverages wholesaling & Distribution & 428.48 & 1086 \\
\hline $\mathrm{R}$ & Livestock breeder & Breeding & \multirow{2}{*}{$\mathrm{N} / \mathrm{A}$} & \multirow{2}{*}{$\mathrm{N} / \mathrm{A}$} \\
\hline $\mathrm{S}$ & Dairy production and sales & Processing & & \\
\hline $\mathrm{T}$ & Food products retail and catering & Retail & 130.13 & 733 \\
\hline $\mathrm{U}$ & Merchandise transportation & Distribution & 168.63 & 583 \\
\hline
\end{tabular}




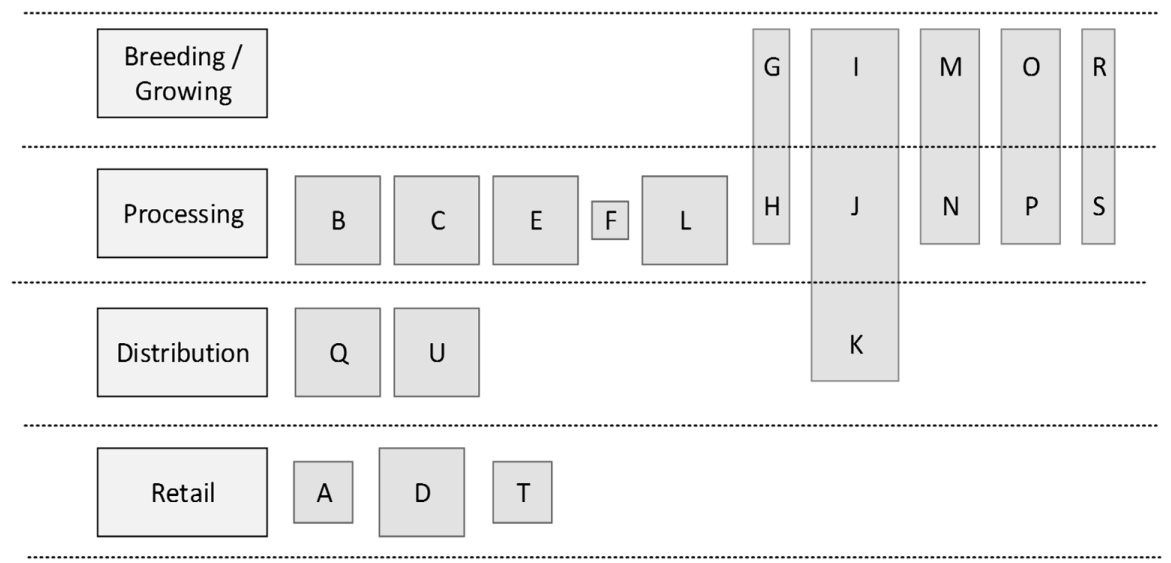

Figure 3. Units of analysis distributed in the food supply chain. Note: Boxes size symbolizes the representative company size.

\subsection{Research Boundaries and Data Collection}

The cases were selected taking into account some of the research boundaries proposed by [50] when doing research in green supply chain management:

- Organizational: the study considers practices and sustainability performance in a company that works in certain FSC stage. In case a firm has operations in more than one stage, the analysis counts each stage separately.

- Proximal: cases are selected in FSCs that have at least one focal company in Italy, with the aim of comparing cases with similar geographic characteristics.

- Temporal: the study considers only sustainability practices in collaboration already adopted, and sustainability performance that was/is expected or perceived. Thus, the study is retrospective.

- Informational: referring to the availability of information, the study analyzes data from interviews and secondary sources (e.g., annual sustainability reports, communication spots, articles published in newspapers).

- Economic: due to confidentiality requirements from the companies interviewed, the study reports the qualitative data regarding sustainability savings or investments/costs.

- Technological: the analysis will not differentiate or evaluate the technology used for sustainability applications or performance evaluation. The technological differences among companies and stages due to company size, capabilities and budget are not focus of this study.

Data was collected mainly through semi-structured interviews conducted at the companies' offices or, according to the preference of the respondents, by telephone. Interviewees were entrepreneurs, CEOs, quality managers, marketing managers and CSR managers. The interviews had an average duration of $90 \mathrm{~min}$. We asked interviewees first to describe the company's supply chain, then we asked about the sustainability practices implemented, in house or in collaboration. For the latter, the interviewee was asked to describe the collaboration in detail. Finally, questions concerning sustainability performance expectations were set (Interview Protocol available on request). Additionally, in case of clarification requests, respondents were contacted by e-mail. In order to ensure validity, information was also gathered from secondary data sources as company webpages, company sustainability reports, and industry news [40,48,51].

\section{Findings and Data Analysis}

Data was analyzed in three steps i.e., within case, cross-case per stage, and cross-stage. Firstly, within each case in order to identify the sustainability practices applied in collaboration. Following, the cross- case within each stage analysis involves the aggregation of the previous findings per FSC 
stage. Finally, a cross-stage analysis allowed identifying the sustainability performance expected from sustainability practices aggregated in the cross-case analysis.

\subsection{Sustainability Practices in Collaboration in the FSC}

Firstly, with the aim of answering RQ1, the sustainability practices in collaboration were identified and tabulated for each case according to the dimensions exhibited in Table 1 . In the set of cases, 58 sustainability practices were identified and categorized, from which 22 were implemented with some type of collaboration i.e., vertical (upstream, downstream) and horizontal (external) [2]. In Table 5, we present the list of the practices we discovered within each FSC stage, where the letters represent the cases that apply the practice. Moreover, the list of practices includes a sub-index: $\mathrm{Cu}, \mathrm{Cd}$, or $\mathrm{Ce}$, meaning if the practice is realized in collaboration with an upstream stage, with a downstream stage or with an external actor, respectively.

Taking into account that almost half of the total sustainability practices implemented by the companies in the sample are collaborative, we observed that companies in the FSC invest in collaboration initiatives in the Processing, Distribution and Retail stages. Collaboration for sustainability in these stages could be explained by the companies seeking to manage the relationships with the sources of dependent resources with their respective supplier in terms of product or raw material availability, and for ensuring product characteristics. Also, companies in these stages recognized the potential benefits of having an external actor helping them to achieve their objectives. Hence, the evidence shows an interest of the companies in the FSC in Italy to establish collaborations as a way to manage interdependencies and reduce uncertainties in the chain. For instance, company $\mathrm{C}$ established horizontal partnerships with external organizations in order to protect marine reserves and to train suppliers in safe fishing processes; this way, the company also ensured its raw material supply in the long-term. Similarly, one interviewee in case D explained that practices in collaboration in the GPPT dimension are put in place for optimizing common resources and guarantee the supply of its private label products. In this company, the reducing packaging project (vertical- upstream collaboration) was launched with suppliers (Processors and Growers) in order to improve both companies' processes and reduce costs:

"The interest is both from suppliers and from $D$, in fact, the project also helps to optimize processes at the supplier side saving a lot of materials and money" (Interviewee Company D)

Company D launched a project on products on which a partnership was already established. This approach confirms the company's interest in reducing its supply risk and improves performance with a long-standing relationship.

On the other hand, shown in Table 5, most practices adopted in collaboration are employed in single cases. The Interviewee in case B mentioned that the types of project (vertical collaboration with suppliers abroad) for spreading cocoa cultivation techniques in an African country took time, patience and money to be fully working, underlining that such an effort is not feasible to apply everywhere because of high costs and different business culture in different countries.

Additional interesting elements were observed in different stages. The first stage, Breeding/ Growing, involved few partnerships on sustainability, most likely as a result of the small size and power of the actors in the first stage and the fact that these are poorly organized. Breeders/growers tend to be small farmers that sell their products to cooperatives, who in turn sell to manufacturers, or farms owned by the corresponding processing companies. From the RDT point of view, the first type of farms in the Breeding/Growing stage might not be able to increase power because of their limited size, even though they control the main raw materials i.e., the input to the following supply chain stages. The companies in this stage are mainly vertically integrated with Processing actors (i.e., a strategy identified by RDT to manage interdependencies and to reduce risk) and collaborations for sustainability aim to guarantee product quality and safety. As company O's interviewee explained: 
Table 5. Sustainability practices implemented in collaboration.

\begin{tabular}{|c|c|c|c|c|c|}
\hline \multicolumn{2}{|c|}{ Sustainability Dimension and Practice * } & Breeding/Growing & Processing & \multirow[t]{2}{*}{ Distribution } & \multirow[t]{2}{*}{ Retail } \\
\hline \multirow{12}{*}{ Environmental } & \multicolumn{3}{|c|}{ Natural Resources Conservation (NRC) } & & \\
\hline & Veterinary checkups (Ce) & $\mathrm{O}, \mathrm{R}$ & & & \\
\hline & Collaboration with NGOs (Ce) & & $\mathrm{C}$ & & \\
\hline & Sustainable fishing $(\mathrm{Ce})$ & & C & & \\
\hline & \multicolumn{5}{|c|}{ Green processing, packaging and transport (GPPT) } \\
\hline & Optimizing transportation (inbound) $(\mathrm{Cu})$ & & $\mathrm{B}, \mathrm{E}, \mathrm{H}, \mathrm{N}$ & & $\mathrm{D}, \mathrm{T}$ \\
\hline & Optimizing transport (outbound) $(\mathrm{Cd})$ & & $\mathrm{B}, \mathrm{C}, \mathrm{H}$ & $\mathrm{K}, \mathrm{Q}, \mathrm{U}$ & \\
\hline & LCA Projects $(\mathrm{Cu})$ & & & & $\mathrm{D}$ \\
\hline & Reducing packaging $(\mathrm{Cu})$ & & E & & $\mathrm{D}, \mathrm{T}$ \\
\hline & Increased transportation capacity (Ce) & & & $\mathrm{U}$ & \\
\hline & Eco-friendly fleet $(\mathrm{Cu})$ & & & & $\mathrm{D}$ \\
\hline & Logistics collaboration $(\mathrm{Cu}, \mathrm{d})$ & & & $\mathrm{Q}, \mathrm{U}$ & $\mathrm{D}$ \\
\hline \multirow{9}{*}{ Social } & \multicolumn{5}{|c|}{ Work and Human Rights (W\&HR) } \\
\hline & Sustainability training $(\mathrm{Ce})$ & & E,P & $\mathrm{Q}, \mathrm{U}$ & \\
\hline & \multicolumn{5}{|c|}{ Community } \\
\hline & Collaboration with NGOs (Ce) & & $\mathrm{C}, \mathrm{E}$ & & $\mathrm{D}, \mathrm{T}$ \\
\hline & Information sharing about consumption $(\mathrm{C} u, d)$ & & $\mathrm{J}$ & $\mathrm{K}, \mathrm{Q}, \mathrm{U}$ & \\
\hline & Donation $(\mathrm{Ce})$ & & $\mathrm{C}$ & & $\mathrm{A}, \mathrm{D}, \mathrm{T}$ \\
\hline & Consumer education $(\mathrm{Ce})$ & & C,E,J & & $\mathrm{D}, \mathrm{T}$ \\
\hline & Volunteering (Ce) & & $\mathrm{C}$ & & \\
\hline & Sustainability projects (Ce) & & & & $\mathrm{T}$ \\
\hline \multirow{7}{*}{ Economic } & \multicolumn{5}{|c|}{ Sustainable Sourcing (SS) } \\
\hline & $\begin{array}{l}\text { Control and improvement partners/suppliers } \\
\qquad(\mathrm{Cu})\end{array}$ & $\mathrm{M}, \mathrm{O}$ & $\mathrm{H}, \mathrm{J}, \mathrm{E}$ & $\mathrm{Q}, \mathrm{U}$ & $\mathrm{A}, \mathrm{D}, \mathrm{T}$ \\
\hline & Sustainable purchasing $(\mathrm{Cu})$ & & $\mathrm{L}$ & & \\
\hline & \multicolumn{5}{|c|}{ Support SC partners } \\
\hline & Spread know-how $(\mathrm{Cu})$ & & $\mathrm{B}, \mathrm{C}$ & & \\
\hline & Advanced payments (Ce) & & B & & \\
\hline & Economic development support $(\mathrm{Cu})$ & & B & & $\mathrm{D}, \mathrm{T}$ \\
\hline
\end{tabular}

* The sub-index in the practices: $\mathrm{Cu}, \mathrm{Cd}$, or $\mathrm{Ce}$, indicates if the practice is realized in collaboration with an upstream stage, with a downstream stage or with an external actor, respectively.

"We undergo continuous strict veterinary controls, combined with the daily care of our breeders/partners -vertical upstream collaboration- that do the rest. Here is how milk with unique quality is obtained: milk is collected and delivered every morning at dawn and then is transported directly to the plant with refrigerated tankers. The plant is only a few kilometers from the partner farm so shipping is fast and safe, to ensure maximum freshness and maintaining unaltered the unmistakable organoleptic qualities"

Similarly, from the Processing side of a vertical integration, company J's interviewee explained how farms are carefully organized and controlled in order to obtain the appropriate quality in the product:

"In the case of the fruit and vegetable industry we have a cultivation disciplinary, also for our integrated production, where the limited use of pesticides is mandatory. Our discipline code enhances our agronomic systems". (Interviewee Company J)

In the Processing stage, many case-specific collaboration initiatives were observed primarily in the larger companies of cases B, C and E, which could be explained by either their size or the higher bargaining power in their respective supply chains. Considering RDT, larger companies in the 
FSC might be focusing on reducing uncertainties and gaining power over other actors when setting up supplier support initiatives, or by sharing resources e.g., in the environmental area: sustainable fishing, reducing packaging; or in the economic: advanced payments, spread know- how. Company B for instance, works with particular banks (horizontal external collaboration) to provide anticipated payment to the farmers associated in cooperatives according to planned production. This initiative implies a cost for company B but at the same time supports better production methods and helps farmers' economic sustainability. In this way, company B increases stability in its supply market, reducing uncertainty of raw material availability, and gaining more control over the dependent resources. In addition, it is relevant to mention that in this FSC stage, the collaboration for sustainability tends to be strictly related to each company's strategy and position in the chain, especially when there is some level of vertical integration upstream.

In the Distribution and Retail stages, a mix of case-specific and recurrent collaborative practices was observed. For the former, as in the Processing stage, larger companies implemented the single-case practices, as in case D with an eco-friendly fleet and LCA (life cycle assessment) projects. The reasoning could be similar: to reduce uncertainties and gaining power. For the latter, recurrent practices are applied as well, regardless of company size e.g., information sharing about consumption, donations, in the social dimension.

The second step of analysis i.e., cross-case within stage, led to the search for patterns across cases in each stage. Although many case-specific practices were observed, some replications per stage were found. Table 6 summarizes these replications along with the collaboration types, taking into account the characteristics listed in Table 2. Practices listed in Table 6 were found at least in two out of the three cases per stage, except for the Processing stage where we report the practices found in at least three cases.

Table 6. Cross-case analysis per stage: Sustainability practices implemented in collaboration.

\begin{tabular}{|c|c|c|c|c|}
\hline SC Stage & \multicolumn{2}{|c|}{ Sustainability Practices } & \multicolumn{2}{|c|}{ Type of Collaborative Approach } \\
\hline \multirow{2}{*}{ Breeding/Growing } & NRC & Veterinary check-ups & External & Transactional \\
\hline & SS & $\begin{array}{l}\text { Partner's control and } \\
\text { development }\end{array}$ & Upstream & Event \\
\hline \multirow{4}{*}{ Processing } & \multirow{2}{*}{ GPPT } & Transport optimization (inbound) & Upstream & Transactional \\
\hline & & $\begin{array}{l}\text { Transport optimization } \\
\text { (outbound) }\end{array}$ & Downstream & Transactional \\
\hline & Community & Consumer education & External & Event \\
\hline & SS & $\begin{array}{l}\text { Partner's control and } \\
\text { development }\end{array}$ & Upstream & Process \\
\hline \multirow{5}{*}{ Distribution } & \multirow[t]{2}{*}{ GPPT } & $\begin{array}{l}\text { Transport optimization } \\
\text { (outbound) }\end{array}$ & Downstream & Transactional \\
\hline & & Logistics collaboration & Downstream/Upstream & Transactional \\
\hline & W\&HR & Sustainability training & External & Transactional \\
\hline & Community & $\begin{array}{l}\text { Information sharing about } \\
\text { consumption }\end{array}$ & Downstream/Upstream & Transactional \\
\hline & SS & $\begin{array}{l}\text { Partner's control and } \\
\text { development }\end{array}$ & External & Process \\
\hline \multirow{7}{*}{ Retail } & \multirow{2}{*}{ GPPT } & Packaging reduction & Upstream & Process \\
\hline & & Transport optimization (inbound) & Upstream & Transactional \\
\hline & \multirow{3}{*}{ Community } & Collaboration with NGOs & External & Event \\
\hline & & Donation & External & Event \\
\hline & & Consumer education & External & Event \\
\hline & SS & $\begin{array}{l}\text { Partner's control and } \\
\text { development }\end{array}$ & Upstream & Process \\
\hline & SC partner support & Economic development support & Upstream & Process \\
\hline
\end{tabular}


First, it can be noted that the majority of collaborations for sustainability are set up (vertically) internally within the supply chains, mostly with the respective upstream actors in a transactional approach. This type of collaboration is a strategy for information exchange, commonly regarding transportation issues. The (vertical) downstream collaborations, though less frequent in our cases, are also implemented in a transactional approach mainly for data sharing. Specifically, Distributors collaborate with large Retailers on practices related to information sharing about emissions, in order to reduce the environmental impact and to communicate this to consumers in sustainability reports. Thus, this approach is as an internal collaboration in the supply chain [2] for certain transactions [26].

Furthermore, the cases provided evidence of certain procedures being established for data collection and communication. This kind of collaboration is set up specifically for managing the current data interdependency in the chain. For instance, Retailers that develop sustainability reports need information from their supply chain partners in order to communicate the best practices to their consumers and stakeholders, therefore a procedure was needed e.g., monitoring kilometers travelled by Distributors for $\mathrm{CO}_{2}$ emissions calculation. However, companies did not expand the use of such data for achieving shared sustainability goals, either because the objectives are different between the actors involved, or because one of the actors does not have the capabilities to handle the data collected. From the RDT point of view, this data dependency management will create new dependencies in the future. For instance, if regulation or reporting requirements change and data collected is no longer sufficient; or if new resources are needed e.g., new transportation means, and new actors in the chain are involved.

The second most frequent type of sustainability practice in collaboration was realized with external actors (e.g., NGOs, industry associations), and half of these, in an event collaborative approach, in Whipple and Russell's definitions. This kind of horizontal collaboration, especially in the Retail stage, was mostly implemented in the social area, within the Community dimension. Larger companies in this stage i.e., $\mathrm{D}$ and $\mathrm{T}$, said to feel a higher external market pressure to act for sustainability, as they are closer to the final consumer. As an example, interviewee from company $\mathrm{T}$ stated:

"if I have a bruised pepper at home, I'll cook it, but when I buy it I want it to be perfect. We, at T, cook products still intact, and do not waste them. We also cooperate with the Food Bank 3 times a year, it is the established procedure. Some products are also collected by organizations that distribute to needy families (products with defective packaging etc.) [ ... .] being the last stage in the chain, we are committed to reduce waste ..."

Additionally, we observed that large Processors and Retailers adopt practices to support community and consumer education through horizontal external collaborations with NGOs. The findings suggest that large companies are prone to this type of collaboration as they feel more exposed to the stakeholders' opinion (i.e., cases C, D, E, T). Moreover, this type of collaboration involves establishing joint planning and decision making for specific events or issues, with explicit and some tacit knowledge sharing; as defined by [26,30] for event collaboration. Therefore, the horizontal collaborations implemented help companies to develop capabilities that otherwise could not be feasible $[27,29,30]$ e.g., educational initiatives, better company reputation, manage food waste donations require partners with the means and competences to carry out the collaboration.

Lastly, Retailers perform sustainability practices in collaboration that go beyond transactional exchanges, prioritizing relationships with specific upstream actors (namely Distributors, Processors or Breeder/Growers), and, focusing their resources on close relationships. This approach is in line with the author in [4] who stated that companies prioritize small number of close relationships, as they need high resources investment. Similarly, authors in [26] suggested that collaboration for event or process require more interaction and performance improvements are expected. Indeed, these practices are relevant for Retailers as they are said to improve their company image, besides, as a response to consumers that are increasingly requiring more "sustainable" (i.e., fair trade and responsible products) 
options in the shelf. Thus, conforming to RDT, Retailers collaborate with the intention of managing stakeholders' expectations and gaining power in terms of upgraded company image.

\subsection{Collaboration Practices and Sustainability Performance in the FSC}

Aiming to address the second research question, the final step in the analysis i.e., cross-stage, offers some insights. Findings suggest that sustainability performance i.e., environmental and social can be associated to some of the collaborative practices implemented in the upstream and or downstream stages. During the data collection process we observed that some specific sustainability practices implemented in (vertical) collaboration are explicitly defined to be applied with some performance expectation for the stage that initiated the collaboration.

This level of analysis includes only the practices related to the expected sustainability performance. Figure 4 displays an extract of the analysis performed, as a matter of example for the Processing stage. The practices implemented in this stage are shown in the darker grey boxes; in addition, the performance expected in the stage upstream (Breeding/Growing) or downstream (Distribution, or Retail), is followed by an indication that refers to " $E$ " for the environmental, while the " $S$ " refers to social sustainability area. For instance, with collaborative practices in the Sustainable Sourcing, Support SC partners and Natural Resources Conservation dimensions, Processors aim to contribute to the environmental performance via soil conservation and animal welfare in the upstream stage (Breeding/Growing). In the Processing stage, the decision to collaborate in the Support SC partner's practices, also projects an improvement of social conditions for the raw material producers (Breeding/Growing). Moreover, the GPPT practices, implemented in collaboration with the downstream actor (Distribution), aim to reduce the distances travelled by Distributors in order to reduce the environmental impact of logistics providers due to lower fuel consumption and emissions of pollutants into the atmosphere (Interviewee case K).

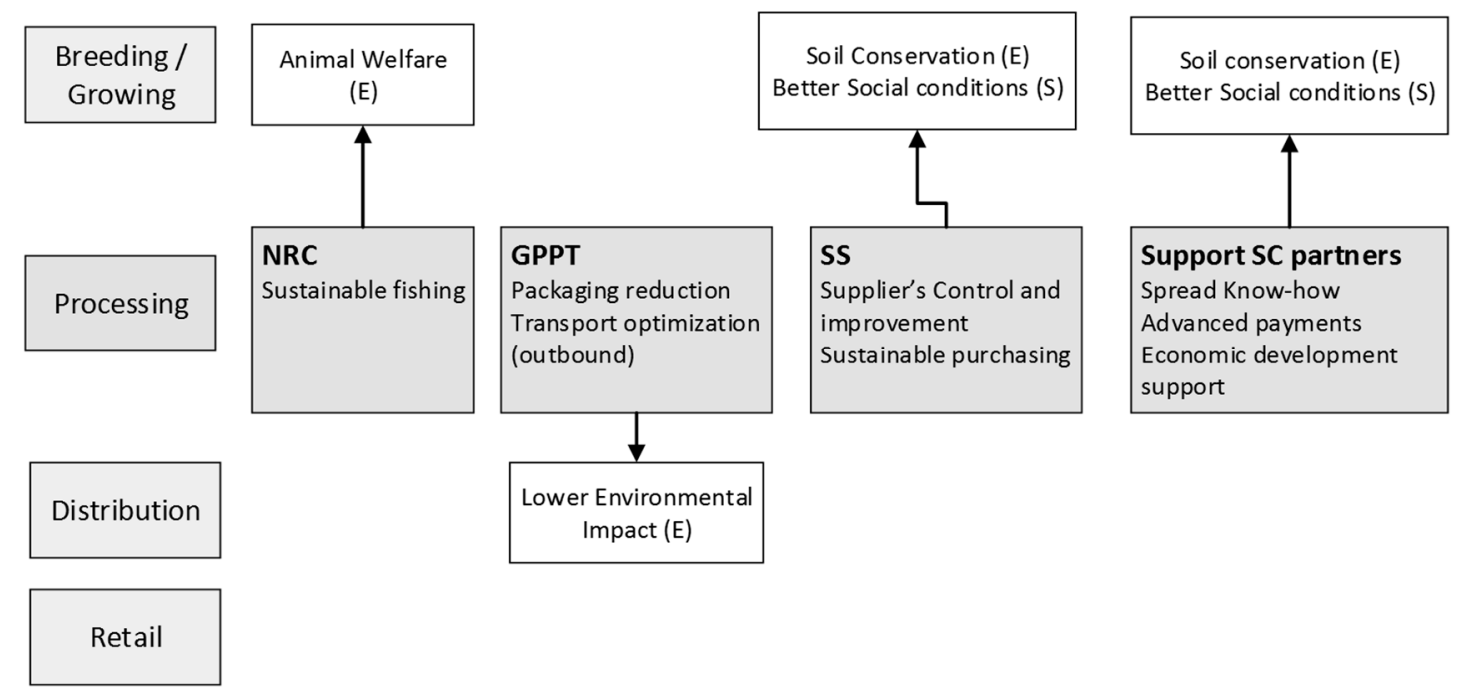

Figure 4. Cross-stage analysis for "Processing" stage.

Similar analyses were performed for the other FSC stages under study. The complete representation of these analyses is shown in Appendix A. For instance, in the Breeding/Growing stage, collaborative practices are aimed to positively influence the environmental impact in this stage itself. However, with other practices as the implementation of traceability systems, the adoption of HACCP (Hazard Analysis and Critical Control Point) protocols; and with collaborative practices in the NRC dimension, farmers expected to positively affect Food Safety along the FSC thus improving the social performance of the downstream stages (Processing, Distribution and Retail) that transform raw materials into finished products, and that offer the product to the final consumer. 
Considering the Distribution stage, the logistic collaborations with large partners, upstream and/or downstream, Processors and/or Retailers, expect to optimize logistics processes (i.e., better transport management and logistic assets sharing), thereby reducing their environmental impact. Even if Distribution is not directly responsible for product quality, this helps to preserve food quality, thanks to the use of tracking and tracing systems, HACCP protocols and temperature control.

Finally, the Retail stage selects its suppliers with particular attention to sustainability requirements, contributing to the sustainability performance upstream (Breeding/Growing, Processing and/or Distribution). For instance, choosing to purchase organic products, Retailers contribute to enlarge this market segment and therefore the percentage of land cultivated in compliance with certain requirements, encouraging farms to reduce their environmental impact. In addition, when requiring its suppliers to sign an ethic code where they commit to be responsible for their workers' conditions, Retailers intend to contribute to social sustainability improvement upstream (Breeding/Growing). Furthermore, in the Retail stage, GPPT practices are often implemented with upstream actors and help to reduce the distances traveled by Distributors. Therefore, they reduce their environmental impact because of the lower fuel consumption and reduced emissions of pollutants into atmosphere. Joint projects of packaging reduction with suppliers (Processors or Growers) also allow companies belonging to the upstream stages to reduce materials use and thereby their environmental impact.

The benefits or gains expected from the implementation of collaborative practices for sustainability can be explained using RDT. As described above, companies in different FSC stages foresee certain performances when they decide to collaborate for sustainability maybe as a matter of ensuring the supply of resources, which they are dependent on e.g., soil conservation and animal welfare will dictate the raw material availability in the future. Furthermore, large companies in the Processing and Retail stages also seek to respond to stakeholder's pressures, to reduce their supply and reputation risk, and to keep or gain power on the relationships that can provide them their main resources for their business. For instance, when actors collaborate for ensuring food safety, the aim is to ensure the final product arrives to the consumer in the best quality conditions, to keep the business running and, to avoid consumers and/or stakeholder complaints. Additionally, companies do not only get their own benefit but also increase the dependency from companies in other stages in the chain. For instance, companies in the Processing and Retail stages depend on effective practices from the Breeding/Growing and Distribution stages; hence, they opt for collaborating among each other in order to ensure the resources coming from them e.g., raw material, food safety. Furthermore, vertically integrated companies, whose directing actors are usually companies in the Processing stage, involved upstream and/or downstream actors as a way to ensure product availability and characteristics, thereby reducing uncertainty.

\section{Conclusions and Final Remarks}

\subsection{General Findings}

Collaboration in supply chain management is proven to enhance a firm's financial performance and create responsiveness towards markets demands [7,30]. Additionally, environmental collaboration with primary suppliers and major customers is said to impact positively on both manufacturing and environmental performance [2,27]. However, several authors have also emphasized the complications related to collaboration in the supply chain i.e., need of resources, risk of failure, increase of dependence, and relationships to be managed $[4,6,29]$. Thus, the need of research beyond focal company or the supplier-customer relationship, and which includes sustainability performance beyond the economic pillar, is recognized in literature [5,21].

Based on a multi-case study approach in four different stages of the food supply chain (FSC), this study is aimed at: (1) identifying and analyzing the sustainability practices implemented in collaboration in different stages in the FSC; and (2) identifying the sustainability performances expected 
from the sustainability practices implemented in collaboration. The FSC stages considered in the study were Breeding/Growing, Processing, Distribution and Retail.

Addressing the first objective, we undertook within-case and cross-case analysis per FSC stage. Findings in this study are aligned with literature regarding environmental collaboration for development of knowledge sharing [2], and for improving one's own firm's performance (see Tables 5 and 6).

In the first stage, collaboration for sustainability, was limited allegedly due to the companies' small size and/or reduced bargaining power. In the Processing stage the tendency to collaborate was more diverse. In line with previous literature $[2,4,7,28,29]$, companies established mainly vertical collaborative relationships with upstream and downstream stages in several sustainability areas including Community, Sustainable Sourcing and Green Processing, Packaging and Transportation. Nevertheless, most of the collaborative initiatives in this stage were found in single cases, depending on the company strategy, size and/or bargaining power. The Distribution stage focused their collaboration initiatives mainly on logistics activities around transport optimization. Lastly, the Retail stage mainly collaborated upstream with suppliers for control and improvement, implementing horizontal collaborations with Community practices e.g., donations, volunteering, and NGOs, in a collaborative event approach. Transactional collaborations were also observed in practices related to transport optimization.

The second objective in the study implied a cross-stage analysis for identifying the sustainability performances expected when collaborative sustainability practices are implemented. Our findings suggest that companies in the FSC collaborate for ensuring supply of dependent resources and/or for gaining benefits or power in the chain. For instance, the collaborative practices in the upstream stage, Breeding/Growing, were carried out to guarantee social sustainability in the consecutive downstream stages, in terms of food safety. By comparison, the Retail and Processing (see Figure 4 for the latter) stages set up collaborations aiming to contribute to soil conservation and better social conditions in the upstream stages by means of Sustainable Sourcing and Support SC partner practices. In this way, companies in these stages could ensure supply in the future, reducing uncertainty and gaining power over dependent resources. Additionally, the practices carried out between Distribution and upstream/downstream stages intended to contribute to environmental sustainability performance of all these stages, thanks to practices that increase logistics processes' efficiency.

\subsection{Contribution to Research and Future Development}

Few studies have considered sustainability in the food supply chain beyond the dyad relationships [52]; this investigation addressed this gap by comparing collaboration for sustainability in four supply chain stages. Identifying each FSC stage's collaboration practices for sustainability, with other stages or external actors, we have provided a holistic view of sustainability-related supply chain strategies.

Similarly, a contribution to literature in this paper is the application of Resource Dependence Theory [15] as a background to explain and understand the collaboration for sustainability that companies in the FSC implement. Two of the strategies proposed by RDT to manage environmental dependences are observed in this study: collaboration (as inter-organizational relationships) and vertical integration. First, companies in the FSC are seen to use collaboration initiatives as a way to reduce uncertainty in the chain and to gain sustainability performance benefits and/or power. Second, some companies decide to vertically integrate (more frequently upstream) as a way to ensure supply with certain product characteristics e.g., organic, quality, safety, easier control and monitoring.

Furthermore, findings in this study show that collaboration for sustainability in different FSC stages is diverse according to the stage, the company size and power, and the level of vertical integration. We found that there is not one single type of collaboration that is applied across food supply chains. This shows the heterogeneity in the FSC regarding sustainability implementation and the type of relationship established among actors for sustainability purposes. Thus, this is evidence of 
the complexity in the FSC where no single standard frame could be used to manage inter-organizational relationships for sustainability. Moreover, this wider view of the supply chain in a specific industry, observing diverse types of relationships, emphasizes the need for developing appropriate performance assessment tools as well.

The second objective in the study was to identify the expected sustainability performance when companies decide to embark on collaborative sustainability practices and this way to extend the existing literature that so far has been prolific on proposing sustainability indicators for one stage [5]. Thus, observing the relationship of sustainability performance intended in a particular FSC stage, thanks to the collaborative practices implemented in other stages, upstream/downstream, corroborates the interrelatedness and interdependency of actions in a supply chain that indeed invites actors to work together for achieving better results. Findings from the analysis performed in this study illustrate that collaborative sustainability practices anticipate performances in other stages, thus creating or reinforcing the dependency among actors, which in turn require stronger relationships. Moreover, given that varied performances are expected as result of the collaborations, appropriate assessment systems will be needed to grasp the progress or not in each actor involved.

The main limitations of our study concern the heterogeneity of companies considered in the study regarding size, product typology and location. Thus, in the future, research is encouraged to analyze the moderation effects of variables such as firm size or product typology in the collaborative approach for sustainability $[7,25]$. In the same line, research could also be extended with a wider sample or a product-specific sample with the aim of exploring if the collaboration and sustainability performance links still apply. Additionally, limitation of the study regards the definition of the performance areas that were inquired to the cases as every area was considered to have the same importance as the others. For instance, food recalls and food waste generation could be an area that is crucial for sustainability in this industry, more than others. Therefore, research could explore the analysis of which sustainability performance areas are being considered more than others and identify the rationale for that kind of behavior. Also for future research, the integration of Resource Dependence Theory and Social Network Theory for explaining sustainability in the supply is also suggested [38]. Moreover, studies could cover metrics and/or measurement processes for sustainability in different FSC stages, in order to understand the appropriateness of the existing methods on each supply chain stage's capabilities and objectives.

\subsection{Implications for Practitioners}

Considering managerial implications, this study provides an overview of the collaborative approaches adopted in different FSC stages which can be useful for setting the most appropriate partnerships, taking into account each one's performance objectives and capabilities. Therefore, identifying the type of collaborative relationship that is beneficial for their own company and their upstream-downstream partners may help to devote the appropriate resources to each initiative. For instance, if a collaborative event relationship were being considered, it would be important for a company to know that it may require mutual willingness to commit for a medium term practice, in order to plan and set goals for performance improvement. Thus, a simple exchange of data would not be enough, or a complete joint process configuration could demand too many resources.

Similarly, the findings in this study are of practitioners' interest for identifying the potential gains of their own sustainability practices on other FSC stages' sustainability performance. This may allow companies to assess their sustainability strategy and collaborative practices according to their individual sustainability objectives, enabling them to learn from their positive and negative results and act in this regard for future improvement [10].

Author Contributions: Verónica León-Bravo, Federico Caniato and Maria Caridi conceived the study. Verónica León-Bravo collected the data and performed the preliminary analysis. Federico Caniato and Maria Caridi supervised the data collection and analysis. Verónica León-Bravo wrote the paper. Federico Caniato, 
Maria Caridi and Thomas Johnsen critically revised and approved the final version of the paper and contributed to the scientific content of the paper.

Conflicts of Interest: The authors declare no conflict of interest.

\section{Appendix A}

Sustainability performance areas associated to the collaboration practices for sustainability implemented in each FSC stage.
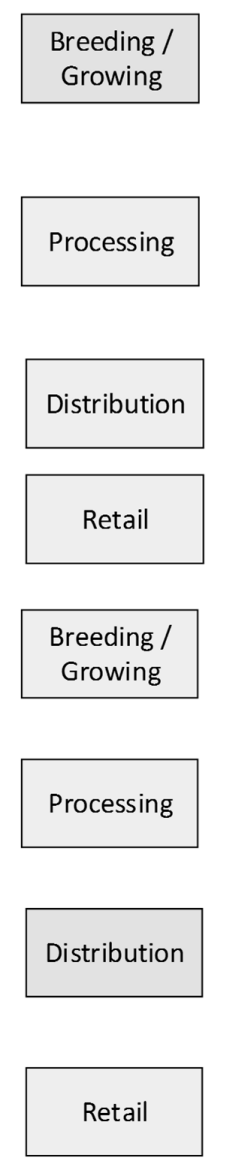

(b)
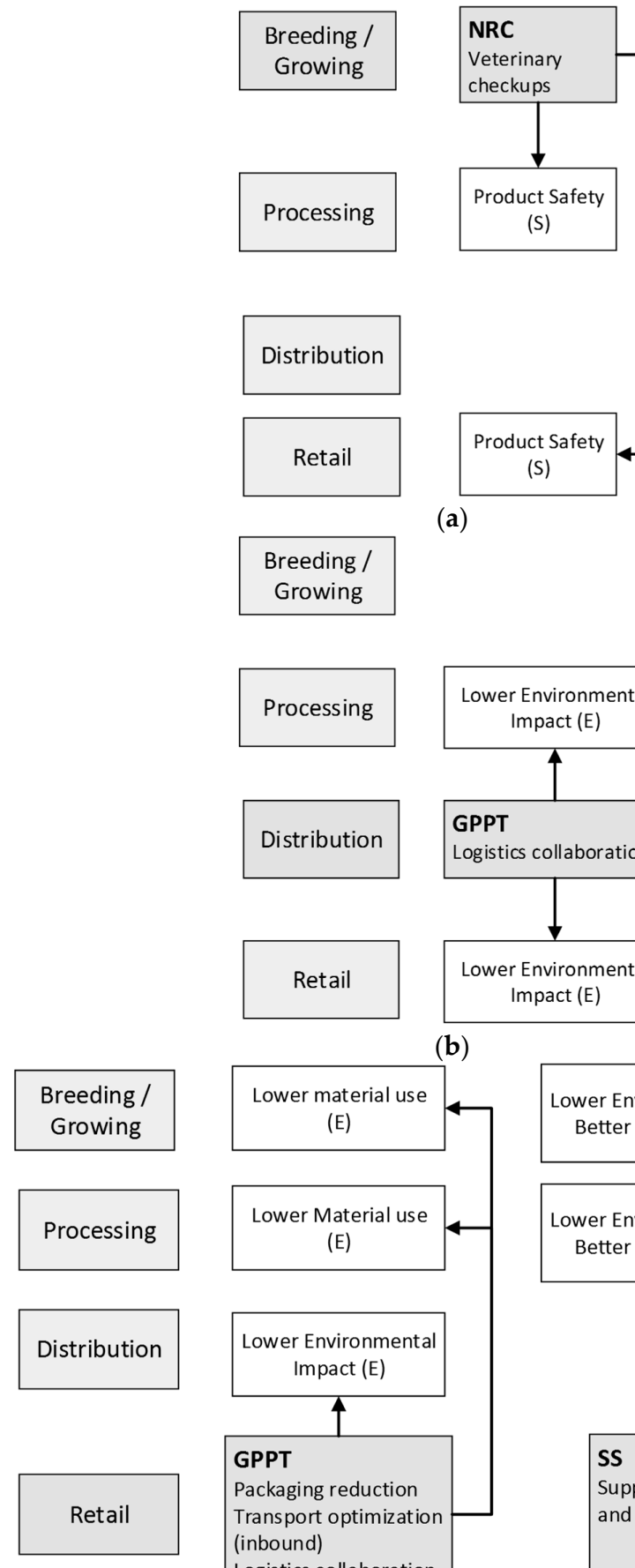

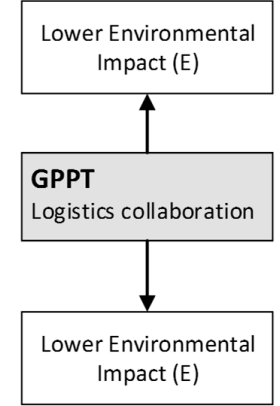

(S)

Product Safety

(S)

(a)

a)

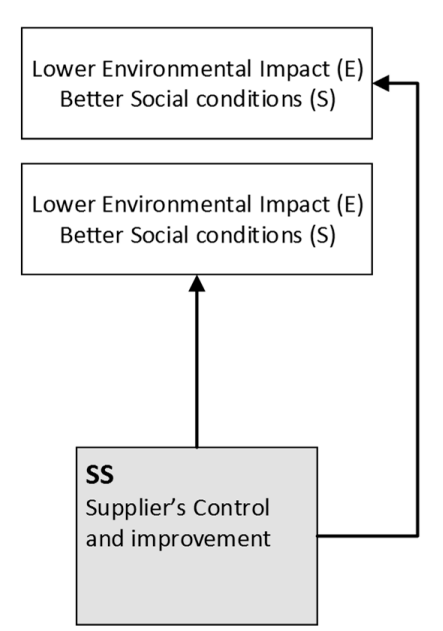

(c)

Figure A1. (a) Breeding/Growing stage; (b) Distribution stage; (c) Retail stage. 


\section{References}

1. The State of Food and Agriculture. Available online: http://www.fao.org/publications/sofa/2013/en/ (accessed on 3 December 2014).

2. Vachon, S.; Klassen, R.D. Environmental management and manufacturing performance: The role of collaboration in the supply chain. Int. J. Prod. Econ. 2008, 111, 299-315. [CrossRef]

3. Ramanathan, U.; Bentley, Y.; Pang, G. The role of collaboration in the UK green supply chains: An exploratory study of the perspectives of suppliers, logistics and retailers. J. Clean. Prod. 2014, 70, 231-241. [CrossRef]

4. Barratt, M. Understanding the meaning of collaboration in the supply chain. Supply Chain Manag. Int. J. 2004, 9, 30-42. [CrossRef]

5. Bourlakis, M.; Maglaras, G.; Gallear, D.; Fotopoulos, C. Examining sustainability performance in the supply chain: The case of the Greek dairy sector. Ind. Mark. Manag. 2014, 43, 56-66. [CrossRef]

6. Matopoulos, A.; Vlachopoulou, M.; Manthou, V.; Manos, B. A conceptual framework for supply chain collaboration: Empirical evidence from the agri-food industry. Supply Chain Manag. Int. J. 2007, 12, 177-186. [CrossRef]

7. Cao, M.; Zhang, Q. Supply chain collaboration: Impact on collaborative advantage and firm performance. J. Oper. Manag. 2011, 29, 163-180. [CrossRef]

8. Hassini, E.; Surti, C.; Searcy, C. A literature review and a case study of sustainable supply chains with a focus on metrics. Int. J. Prod. Econ. 2012, 140, 69-82. [CrossRef]

9. Varsei, M.; Soosay, C.A.; Fahimnia, B.; Sarkis, J. Framing sustainability performance of supply chains with multidimensional indicators. Supply Chain Manag. Int. J. 2014, 19, 242-257. [CrossRef]

10. Pullman, M.E.; Maloni, M.J.; Carter, C.R. Food for thought: Social versus environmental sustainability practices and performance outcomes. J. Supply Chain Manag. 2009, 45, 38-54. [CrossRef]

11. Yakovleva, N.; Sarkis, J.; Sloan, T.W. Sustainability indicators for the food supply chain. In Environmental Assessment and Management in the Food Industry: Life Cycle Assessment and Related Approaches; Sonesson, U., Berlin, J., Ziegler, F., Eds.; Woodhead Publishing: Cambridge, UK, 2010; pp. 297-329.

12. Matopoulos, A.; Bourlakis, M. Sustainability practices and indicators in food retail logistics: Findings from an exploratory study. J. Chain Netw. Sci. 2010, 10, 207-218. [CrossRef]

13. Erol, I.; Sencer, S.; Sari, R. A New fuzzy multi-criteria framework for measuring sustainability performance of a supply chain. Ecol. Econ. 2011, 70, 1088-1100. [CrossRef]

14. Yakovleva, N.; Sarkis, J.; Sloan, T. Sustainable benchmarking of supply chains: The case of the food industry. Int. J. Prod. Res. 2012, 50, 1297-1317. [CrossRef]

15. Pfeffer, J.; Salancik, G.R. The External Control of Organizations: A Resource Dependence Perspective; Stanford University Press: Stanford, CA, USA, 2003.

16. Touboulic, A.; Chicksand, D.; Walker, H. Managing imbalanced supply chain relationships for sustainability: A power perspective. Decis. Sci. 2014, 45, 577-619. [CrossRef]

17. Fritz, M.; Schiefer, G. Food chain management for sustainable food system development: A European research agenda. Agribusiness 2008, 24, 440-452. [CrossRef]

18. Carter, C.R.; Rogers, D.S. A framework of sustainable supply chain management: Moving toward new theory. Int. J. Phys. Distrib. Logist. Manag. 2008, 38, 360-387. [CrossRef]

19. Maloni, M.J.; Brown, M.E. Corporate social responsibility in the supply chain: An application in the food industry. J. Bus. Ethics 2006, 68, 35-52. [CrossRef]

20. Sustainability Pathways. Available online: http://www.fao.org/nr/sustainability/food-loss-and-waste/en/ (accessed on 10 February 2015).

21. Kaipia, R.; Dukovska-Popovska, I.; Loikkanen, L. Creating sustainable fresh food supply chains through waste reduction. Int. J. Phys. Distrib. Logist. Manag. 2013, 43, 262-276. [CrossRef]

22. Vieira, L.M.; De Barcellos, M.D.; Hoppe, A.; da Silva, S.B. An analysis of value in an organic food supply chain. Br. Food J. 2013, 115, 1454-1472. [CrossRef]

23. Gold, S.; Hahn, R.; Seuring, S. Sustainable supply chain management in "Base of the Pyramid" food projects-A path to triple bottom line approaches for multinationals? Int. Bus. Rev. 2013, 22, 784-799. [CrossRef]

24. Rota, C.; Reynolds, N.; Zanasi, C. Sustainable Food Supply Chains: The Role of Collaboration and Sustainable Relationships. Int. J. Bus. Soc. Sci. 2013, 4, 45-53. 
25. Hubeau, M.; Marchand, F.; Van Huylenbroeck, G. Sustainability Experiments in the Agri-Food System: Uncovering the Factors of New Governance and Collaboration Success. Sustainability 2017, 9, 1027. [CrossRef]

26. Whipple, J.M.; Russell, D. Building supply chain collaboration: A typology of collaborative approaches. Int. J. Logist. Manag. 2007, 18, 174-196. [CrossRef]

27. Pero, M.; Moretto, A.; Bottani, E.; Bigliardi, B. Environmental Collaboration for Sustainability in the Construction Industry: An Exploratory Study in Italy. Sustainability 2017, 9, 125. [CrossRef]

28. Chen, L.; Zhao, X.; Tang, O.; Price, L.; Zhang, S.; Zhu, W. Supply chain collaboration for sustainability: A literature review and future research agenda. Int. J. Prod. Econ. 2017, in press. [CrossRef]

29. Chkanikova, O. Sustainable Purchasing in Food Retailing: Interorganizational Relationship Management to Green Product Supply. Bus. Strat. Environ. 2016, 25, 478-494. [CrossRef]

30. Nuhoff-Isakhanyan, G.; Wubben, E.F.; Omta, S.W.F. Sustainability benefits and challenges of inter-organizational collaboration in Bio-Based business: A systematic literature review. Sustainability 2016, 8, 307. [CrossRef]

31. Beske-Janssen, P.; Johnson, M.P.; Schaltegger, S. 20 years of performance measurement in sustainable supply chain management-What has been achieved? Supply Chain Manag. Int. J. 2015, 20, 664-680. [CrossRef]

32. Slaper, T.; Hall, T. The triple bottom line: What is it and how does it work? Indiana Bus. Rev. 2011, 86, 4.

33. Manzini, R.; Accorsi, R. The new conceptual framework for food supply chain assessment. J. Food Eng. 2013, 115, 251-263. [CrossRef]

34. Global Reporting Initiative. 2013. Available online: https://www.globalreporting.org/standards/gristandards-download-center/?g=db250470-931c-4d36-b368-880542d00ee7 (accessed on 8 December 2016).

35. The Sustainability Yearbook 2014. Available online: http://www.p-plus.nl/resources/articlefiles/ SustainabilityYearbook2014.pdf (accessed on 5 December 2015).

36. Seuring, S.; Müller, M. From a literature review to a conceptual framework for sustainable supply chain management. J. Clean. Prod. 2008, 16, 1699-1710. [CrossRef]

37. Mena, C.; Humphries, A.; Choi, T.Y. Toward a Theory of Multi-Tier Supply Chain Management. J. Supply Chain Manag. 2013, 49, 58-77. [CrossRef]

38. Sarkis, J.; Zhu, Q.; Lai, K.H. An organizational theoretic review of green supply chain management literature. Int. J. Prod. Econ. 2011, 130, 1-15. [CrossRef]

39. Chicksand, D.; Watson, G.; Walker, H.; Radnor, Z.; Johnston, R. Theoretical perspectives in purchasing and supply chain management: An analysis of the literature. Supply Chain Manag. Int. J. 2012, 17, 454-472. [CrossRef]

40. Voss, C.; Tsikriktsis, N.; Frohlich, M. Case research in operations management. Int. J. Oper. Prod. Manag. 2002, 22, 195-219. [CrossRef]

41. Banterle, A.; Cereda, E.; Fritz, M. Labelling and sustainability in food supply networks: A comparison between the German and Italian markets. Br. Food J. 2013, 115, 769-783. [CrossRef]

42. Beske, P.; Land, A.; Seuring, S. Sustainable supply chain management practices and dynamic capabilities in the food industry: A critical analysis of the literature. Int. J. Prod. Econ. 2014, 152, 131-143. [CrossRef]

43. Scaling up Global Food Security and Sustainable Agriculture. Available online: https://www. unglobalcompact.org/resources/320 (accessed on 3 November 2014).

44. Food Safety in the EU. Available online: https://europa.eu/european-union/topics/food-safety_en (accessed on 15 November 2016).

45. Principles of Organic Agriculture. Available online: http://www.ifoam.bio/sites/default/files/poa_ english_web.pdf (accessed on 15 July 2015).

46. Setting Social and Environmental Standards-ISEAL Code of Good Practice. Available online: http:/ / www. isealalliance.org/sites/default/files/ISEAL\%20Standard\%20Setting\%20Code\%20v6\%20Dec\%202014.pdf (accessed on 15 July 2015).

47. Van der Vorst, J.G.; Peeters, L.; Bloemhof, J.M. Sustainability assessment framework for food supply chain logistics: Empirical findings from Dutch food industry. In Proceedings of the 6th International European Forum on System Dynamics and Innovation in Food Networks, Innsbruck, Austria, 18-22 February 2013; pp. 480-491.

48. Yin, R.K. Case Study Research: Design and Methods, 4th ed.; Sage Publications: Thousand Oaks, CA, USA, 2009; p. 240. 
49. Eisenhardt, K.M.; Graebner, M.E. Theory building from cases: Opportunities and challenges. Acad. Manag. J. 2007, 50, 25-32. [CrossRef]

50. Sarkis, J. A boundaries and flows perspective of green supply chain management. Supply Chain Manag. Int. J. 2012, 17, 202-216. [CrossRef]

51. Seuring, S.A. Assessing the rigor of case study research in supply chain management. Supply Chain Manag. Int. J. 2008, 13, 128-137. [CrossRef]

52. Walker, H.; Seuring, S.; Sarkis, J.; Klassen, R. Sustainable operations management: Recent trends and future directions. Int. J. Oper. Prod. Manag. 2014, 34. [CrossRef]

(C) 2017 by the authors. Licensee MDPI, Basel, Switzerland. This article is an open access article distributed under the terms and conditions of the Creative Commons Attribution (CC BY) license (http:// creativecommons.org/licenses/by/4.0/). 